\title{
Tolerance to Aluminum Toxicity by Tropical Leguminous Plants Used as Cover Crops
}

\author{
Anderson Rotter Meda and Pedro Roberto Furlani* \\ Instituto Agronômico - IAC; Centro de Pesquisa e Desenvolvimento de Solos e Recursos Ambientais; C. P. 28; \\ 13001-970; Campinas - SP - Brazil
}

\begin{abstract}
The objectives of this work were to compare Al tolerance among 17 species of tropical leguminous plants and to evaluate the most appropriate plant characteristic and Al concentration in nutrient solution for tolerance assessment. In addition, three soybean cultivars were included for comparison purposes. There was a great difference among the 17 plant materials tested, when compared by relative root elongation and critical Al activity to reduce $50 \%$ of root net elongation. Based on these parameters and on the comparison of two tropical maize genotypes differing in Al tolerance, the following classification was established: highly tolerant, for Mucuna nivea, M. deeringiana, M. aterrima Vigna unguiculata cv. BR 17 and Lablab purpureus $c v$. Rongai; tolerant for Cajanus cajan cv. IAPAR 43, Canavalia brasiliensis, Calopogonium mucunoides, Cajanus cajan cv. Fava larga, and Crotalaria paulina; moderately tolerant for Crotalaria ochroleuca, Canavalia ensiformis, Crotalaria spectabilis, and $\mathrm{C}$. mucronata; ; and sensitive for Neonotonia wightii, Crotalaria breviflora and $\mathrm{C}$. juncea cv.IAC-KRl. The three soybeans cultivars were classified as moderately tolerant (Biloxi) and tolerant (IAC 13 and IAC 9).
\end{abstract}

Key words: Nutrient solution culture, root growth, dry matter yields, Al speciation

\section{INTRODUCTION}

Green manuring is a traditional technique used for conservation and recovery of soils in crop rotation, which is based on the cultivation of high biomass producing cover crops and incorporation of the undecomposed green plant tissue into the soil (Karlen et al., 1994). Among the benefits of green manuring are the improvements of acid soil chemistry (Meda et al., 2001), physical properties (Perin et al., 2002) and biological properties of soils (Debarba and Amado, 1997), which reflects directly on yield increase of agricultural crops (Wutke et al., 1998; Amado et al., 1999; Arf et al., 1999).
Leguminous cover crops are the species mainly employed in green manuring, due to their capacity of nitrogen fixation, which tend to decrease the need for N-based fertilizers in crops (Spagnollo et al., 2002). These plants, however, may have other benefits, such as control of nematodes in soil, protein bank and forage for ruminants (Kerridge, 1978), weed control (Favero et al., 2001), and grain production for human nutrition (Barcelos et al., 1999). However, some studies showed that these plants have a differential capacity to overcome nutritional stresses in soil. Ernani et al., (2001) demonstrated that some tropical leguminous plants had singular responses to lime additions in acid soils, what may be related to acid soil tolerance in those species.

\footnotetext{
* Author for correspondence
} 
Soil acidity is a limiting factor to crop growth and it is usually associated to high levels of aluminum (Olmos and Camargo, 1976). The effect of aluminum is initially in root-growth inhibition, resulting in lesser exploration of bulk soil and lesser uptake of water and nutrients. Particularly for leguminous plants, nitrogen fixing may be severely affected by Al toxicity in subsoil (Silva and Sodek, 1997). These consequences, taken together, may decrease carbon sequestration and biomass formation, which is the key for nutrient recycling in soil (Alcântara et al., 2000), physical protection of soil against high temperatures (Oliveira et al., 2002) and erosion (Nascimento and Lombardi Neto, 1999), weed control (Severino and Christoffoleti, 2001), nitrogen incorporation (Debarba and Amado, 1997) and addition of organic carbon to soil (Testa et al., 1992).

Recently there has been great interest in tropical leguminous plants, because of the increased adoption of green manuring in Brazilian cerrados (savannah) (Amado et al., 1999) and fruitproducing regions, for example in citrus orchards (Silva et al., 2002b) as a result of the necessity of a stable and sustainable production. Despite of the importance of tropical leguminous cover crops in Brazil, there is no information about $\mathrm{Al}$ toxicity reaction by the main species employed for this purpose.

The objectives of this work were to compare $\mathrm{Al}$ tolerance among 17 tropical leguminous plants and to evaluate the most appropriate parameter and $\mathrm{Al}$ concentration (activity) in nutrient solution for tolerance assessment.

\section{MATERIAL AND METHODS}

The experiment was carried out under greenhouse conditions, in 2002, at the Center of Soils and Environmental Resources, Instituto Agronômico (IAC), Campinas, Brazil. The experimental design consisted of complete randomized blocks, in splitplots with three replications. The treatments in the main plots were the $\mathrm{Al}$ concentrations $(0,111$, 222, 333 and $444 \mu \mathrm{mol} / \mathrm{L}$ of $\left.\mathrm{AlK}\left(\mathrm{SO}_{4}\right)_{2} .12 \mathrm{H}_{2} \mathrm{O}\right)$ and in the subplots, 17 leguminous cover crop species and cultivars, 3 soybean cultivars and 2 tropical maize cultivars contrasting as for $\mathrm{Al}$ tolerance. The air temperature and air relative humidity were registered during the entire experimental period. The means and standard deviation for the calculated means for the highest and lowest temperatures were $36.8 \pm 2.8^{\circ} \mathrm{C}$ and $19.5 \pm 1.3^{\circ} \mathrm{C}$, respectively.. For the air relative humidity the averages were $89.3 \pm 2.9 \%$ and $38.5 \pm 6.0 \%$, respectively.

The species and cultivars used in this study were: Cajanus cajan, cvs. Fava larga and IAPAR 43, Calopogonium mucunoides, Canavalia brasiliensis, Canavalia ensiformis, Crotalaria breviflora, Crotalaria juncea, cv. IAC-KR1, Crotalaria ochroleuca, Crotalaria mucronata, Crotalaria paulina, Crotalaria spectabilis, Lablab purpureus cv. Rongai, Mucuna nivea, Mucuna deeringiana, Mucuna aterrima, Neonotonia wightii, Vigna unguiculata cv. BR 17 and soybean (Glycine max) cultivars (IAC 13, IAC 9 and Biloxi). Besides the green manure species and soybean cultivars, maize (Zea mays) cultivars Taiuba tolerant and Taiuba sensitive to $\mathrm{Al}$ were included as references (Furlani et al., 2000).

Seeds were surface-treated with thiabendazole and germinated in moistened papers (type CEL-065) with tap water containing $500 \mu \mathrm{mol} / \mathrm{L}$ of $\mathrm{Ca}$. Preliminary germination test done for each of the plant especies studied, led us to use seedlings of different age (three- to seven-days old) in order to have plants with an average $9.6 \mathrm{~cm}$ root length that were transplanted to recipients with nutrient solution. The experimental unit consisted of a plastic vessel with $13 \mathrm{~L}$ of nutrient solution with a silver-painted acrylic lid (to avoid light in roots) holding seven seedlings of each specie/cultivar, inserted in holes and supported by sponge beads, in a total of 154 plants/vessel.

The nutrient solution used for plant growth had the following chemical composition (in $\mu \mathrm{mol} / \mathrm{L}$ ): $\mathrm{N}$ $\mathrm{NO}_{3} 3750, \mathrm{~N}-\mathrm{NH}_{4} 300, \mathrm{P} 30, \mathrm{~K}$ 1280, Ca 1250, $\mathrm{Mg} 500, \mathrm{~S}_{-} \mathrm{SO}_{4}$ 500, B-B $(\mathrm{OH})_{4} 11.5, \mathrm{Cu} 1.9310^{-2}$, Fe-EDDHA 225, Mn 2.25, Mo- $\mathrm{MoO}_{4} 1.3010^{-1}$ and $\mathrm{Zn} 0.4810^{-1}$, based on Pavan and Bingham (1982). The nutrient solution was constantly aerated and the $13 \mathrm{~L}$ volume was maintained by daily additions of deionized water. Solutions were completely replaced after 3 and 6 days. $\mathrm{pH}$ and electrical conductivity (EC) was monitored during the entire experiment and chemically analyzed (macro and micronutrients) before and after solution's refreshment. This allowed the estimation of $\{\mathrm{Al}\}$ activity in solution based on stability constants described by Nordstrom and May (1989) and computation by GEOCHEM-PC 2.0 (Parker et al., 1987). 
Before transplanting, root length was measured and after 9 days in nutrient solution plants were harvested and root length was again registered, for determination of root net length (RNL). Shoots and roots were separated, placed in paper bags and taken to a forced-dry oven at $70^{\circ} \mathrm{C}$ until constant mass, for determination of dry matter yield. The effects of $\mathrm{Al}$ on shoot and root dry matter yields were evaluated by means of linear and quadratic polynomial regression.

Al tolerance was quantified by estimation of the mean relative net elongation (RNEm) by the following expression: $\mathrm{RNE}=\mathrm{RNL}$ in the presence of $\mathrm{Al} / \mathrm{RNL}$ in control. For each $\mathrm{Al}$ level a RNE value was obtained. The estimation of RNEm was based on the means of RNE in the five Al levels. Data was submitted to analysis of variance and Tukey's test at 5\% was used to compare the significant means (Zonta et al., 1987).

Critical $\mathrm{Al}$ concentration $[\mathrm{Al}]_{50}$ and $\mathrm{Al}$ activity $\{\mathrm{Al}\}_{50}$ to reduce $50 \%$ of RNL were calculated for each plant material. RNL was regressed against $\mathrm{Al}$ concentrations and activities using the TableCurve 2D 5.0 software package (Systat, 2002). Polynomial algorithms were the best-fit functions $\left(\mathrm{r}^{2}=1,00\right)$ and hence permitted the calculation of $[\mathrm{Al}]_{50}$ and $\{\mathrm{Al}\}_{50}$.

\section{RESULTS}

\begin{abstract}
Aluminum activity in nutrient solution
The estimated aluminum activity $(\mu \mathrm{mol} / \mathrm{L})$, in the solutions with $\mathrm{Al}$ varied, on average from 23.8 to $14.9,42.3$ to $26.2,54.6$ to 41.7 and 70.5 to 56.7 before and after the replacement of the nutrient solutions with the following total Al levels: 111, 222,333 and $444 \mu \mathrm{mol} / \mathrm{L}$, respectively. The free specie $\mathrm{Al}^{3+}$ was predominant in solution $(\sim 50 \%)$, in relation to other monomeric $\mathrm{Al}$ species.
\end{abstract}

\section{Symptoms of Al toxicity}

The presence of $\mathrm{Al}$ in nutrient solution caused a delay in the vegetative growth of the plants, with less emission of leaves and decreased development of shoots, directly proportional to $\mathrm{Al}$ level in solution. Al toxicity symptoms in roots were evident after 2 days from transplanting, such as lateral root inhibition, darkening and shrinking, which were greater with higher concentration of $\mathrm{Al}$ in solution.

The maize cultivar Taiuba sensitive confirmed its reaction to $\mathrm{Al}$, presenting a high sensitivity to 111 $\mu \mathrm{mol} / \mathrm{L}$ of Al. Purple color and internerval leaf chlorosis was observed in shoot of Al-stressed plants. On the other hand, the cultivar Taiuba tolerant did not present any symptoms of $\mathrm{Al}$ toxicity in shoots in this concentration. Above this concentration, $\mathrm{P}$ deficiency and chlorosis was also observed. However, this cultivar confirmed its tolerant reaction to $\mathrm{Al}$ toxicity.

There was a great difference among the plant materials as to their reaction to Al. For instance, in C. juncea, the $111 \mu \mathrm{mol} / \mathrm{L}$ of $\mathrm{Al}$ concentration caused a root-tip curling and apparently interrupted its growth. Conversely, the roots of Mucuna plants in dose of $111 \mu \mathrm{mol} / \mathrm{L}$ of $\mathrm{Al}$ had the same appearance as control plants, demonstrating a higher capacity of this group of plants to tolerate this concentration of $\mathrm{Al}$.

\section{Dry matter yields}

A great variation among plant materials was also obtained for shoot and root dry matter yields, but significant differences were only due to species/cultivar effect, not Al. Considering the mean dry matter production for all the species, there was a significant $(\mathrm{P}<0.05)$ linear and quadratic effect, indirectly proportional to $\mathrm{Al}$ levels. However, low dry matter-producing plants did not present any significant response to $\mathrm{Al}$ doses, such as $C$. cajan, $C$. juncea, $C$. paulina, $C$. mucunoides, $C$. spectabilis, $N$. wighiti., $C$. breviflora, $C$. mucronata and C. ochroleuca. These plants presented a low growth rate and, therefore, it was not possible to observe a difference in dry matter yield in the different $\mathrm{Al}$ levels after 9 days in nutrient solution. Even those that presented a significant response, like Mucuna species, it was observed reduction at $\mathrm{Al}$ doses higher than $222 \mu \mathrm{mol} / \mathrm{L}$ and increase in dry matter production for lower doses of $\mathrm{Al}$ (data not shown).

\section{Root net length (RNL) and mean relative root net elongation (RNEm)}

Root net length, which represented the effective root growth during the experimental period, varied significantly among the plant materials tested. Roots, on average grew $(\mathrm{cm}) 26.6,12.3,6.8,4.9$ and 3.7 in $0,111,222,333$ and $444 \mu \mathrm{mol} / \mathrm{L}$ of total $\mathrm{Al}$ in nutrient solution, with significant quadratic effects $(\mathrm{P}<0.05)$. Thus, there was a clear effect of $\mathrm{Al}$ toxicity, proportionally related to $\mathrm{Al}$ doses. In fig. 1 is shown the values of RNEm for each plant material (refer to material and 
methods), which can be considered as a quantification of $\mathrm{Al}$ tolerance.

Table 1 demonstrated the classification of plant materials as for their reaction to $\mathrm{Al}$ toxicity and the critical values of $\mathrm{Al}$ concentration and activity in nutrient solution. This classification was established based on data presented in Fig. 1 and the critical Al thresholds. The materials considered tolerant had the same or superior behavior as the tolerant maize cultivar, whereas the same criterion was used for those plant materials with a similar reaction to the sensitive maize cultivar.

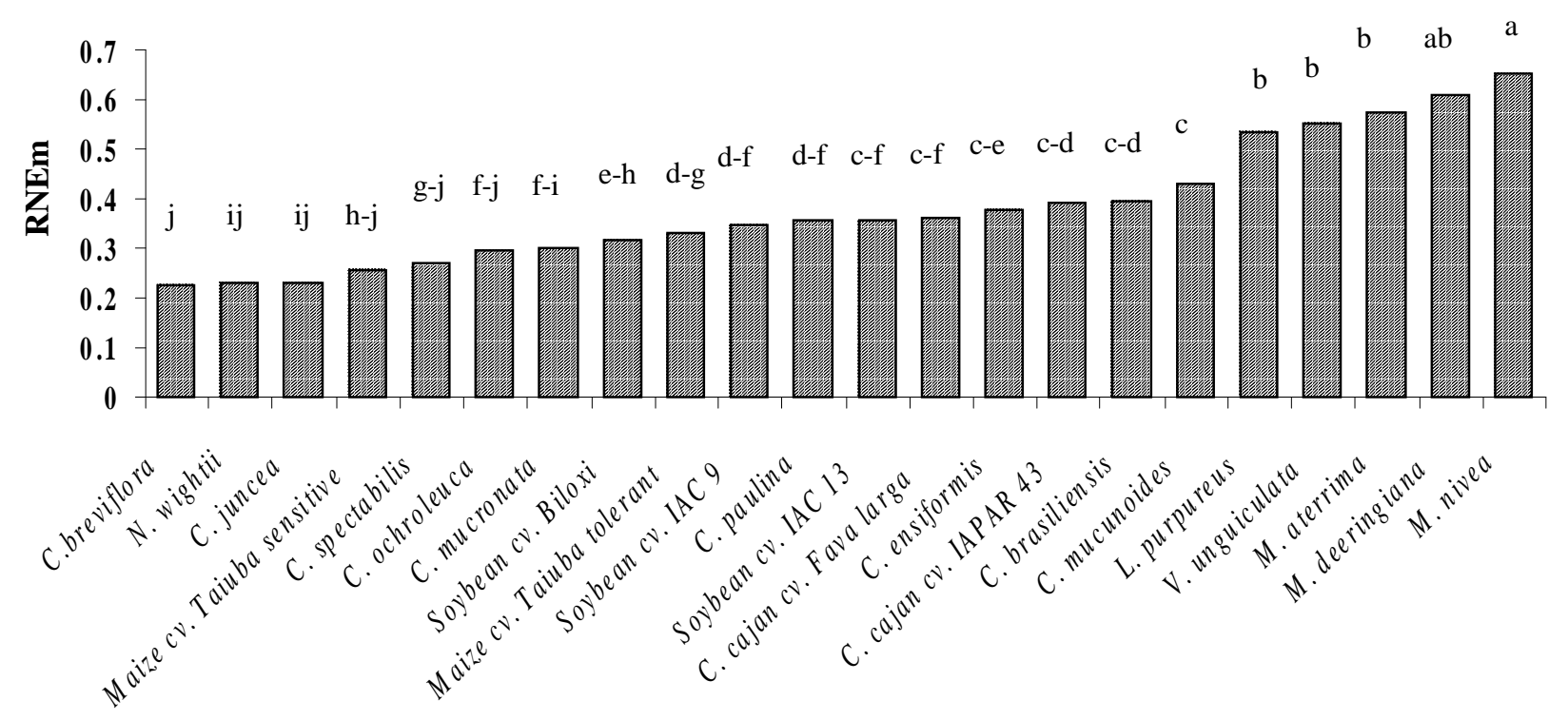

Figure 1 - Mean relative root net elongation (RNEm) of 20 leguminous plants and 2 maize cultivars after 9 days of cultivation in nutrient solution, with five Al levels. Columns with same letters do not differ statistically at Tukey's test $(\mathrm{P}<0.05)$.

\section{DISCUSSION}

Aluminum toxicity causes significant changes in biochemical and structural pattern of plant cells, reflecting on reduction of cell multiplication (Minocha et al., 1992) and cell growth, altering auxin action in cell-wall loosening and synthesis (Ma et al., 1999). Normally the root is the plant organ most affected by Al toxicity, and more specifically the root tip is considered to be the main site for Al toxicity (Archambault et al., 1997). As a result, root elongation is considered to be the most sensitive parameter in a short period of time, and thus may represent the whole-plant reaction to Al. Noble et al., (1988) demonstrated that in $24 \mathrm{~h}$ it was possible to observe damages caused by $\mathrm{Al}$ in roots of soybean plants, directly proportional to $\mathrm{Al}$ concentrations in nutrient solution, as demonstrated in the present experiment.

Recent studies by Silva et al. (2000) showed by fluorescence images, that within just $30 \mathrm{~min}$, Al entered in cell symplast, accumulating in the nucleus of meristematic cells of soybean roots, causing a decrease in root growth. The observation of $\mathrm{Al}$ toxicity symptoms, like root darkening and root-tip shrinking, in this experiment in a short period of time ( $48 \mathrm{~h}$ ), could be related to the rapid entrance of $\mathrm{Al}$ in root cells. The root morphological alterations, like shrinking and tip curling, observed in roots of some of the plant materials tested could be attributed to alterations in cytoskeleton (Blancaflor et al., 1998; Horst et al., 1999). These authors showed that changes in organization and stability of microtubules and microfilaments in root cells of maize were correlated to $\mathrm{Al}$ toxicity, besides the rapid inhibition of root elongation.

In the present experiment, dry matter yields did not permit a discrimination of plant materials for Al tolerance. On the other hand, root elongation was the best parameter to compare Al tolerance among the plant materials. Braccini et al. (2000b) also reported that in the presence of $\mathrm{Al}$, root 
elongation of coffee genotypes was more affected than root dry matter. Bernal and Clark (1998) observed that differences in dry matter production in sorghum genotypes were not as significant as root elongation, the latter being the best discrimination parameter. The results obtained by Mascarenhas et al. (1984) indicated that root length of seedlings was better than shoot and root dry matter yield to evaluate Al tolerance among soybean genotypes.
Root elongation has been considered the most sensitive characteristic to quantify $\mathrm{Al}$ tolerance due to the fact that the elongation zone is the site where Al toxicity is primarily detected (Blancaflor et al., 1998). Particularly, the distal transition zone (DTZ) is the most sensitive site for $\mathrm{Al}$ action in root (Kollmeier et al., 2000). These authors showed that application of Al solution exclusively in DTZ inhibited root elongation in a similar pattern to whole-root application.

Table 1 - Reaction to $\mathrm{Al}$ toxicity and critical values for $\mathrm{Al}$ concentration $[\mathrm{Al}]_{50}$ and $\mathrm{Al}$ activity $\{\mathrm{Al}\}_{50}$ for $50 \%$ reduction of root net length of 20 leguminous plants and 2 maize cultivars

\begin{tabular}{|c|c|c|c|}
\hline Plant material & {$[\mathrm{Al}]_{50}$} & $\{\mathrm{Al}\}_{\mathbf{5 0}}$ & Reaction to Aluminum \\
\hline Crotalaria juncea & 39 & 11 & sensitive \\
\hline Maize cv. Taiuba sensitive & 39 & 11 & sensitive \\
\hline Crotalaria breviflora & 42 & 12 & sensitive \\
\hline Neonotonia wightii & 43 & 12 & sensitive \\
\hline Crotalaria mucronata & 58 & 15 & moderately tolerant \\
\hline Crotalaria spectabilis & 65 & 16 & moderately tolerant \\
\hline Maize cv. Taiuba tolerant & 68 & 17 & moderately tolerant \\
\hline Canavalia ensiformis & 73 & 18 & moderately tolerant \\
\hline Crotalaria ochroleuca & 75 & 18 & moderately tolerant \\
\hline Soybean cv. Biloxi & 80 & 19 & moderately tolerant \\
\hline Crotalaria paulina & 88 & 21 & tolerant \\
\hline Soybean cv. IAC 13 & 92 & 21 & tolerant \\
\hline Cajanus cajan cv. Fava larga & 95 & 22 & tolerant \\
\hline Calopogonium mисunoides & 97 & 22 & tolerant \\
\hline Soybean cv. IAC 9 & 100 & 23 & tolerant \\
\hline Canavalia brasiliensis & 104 & 23 & tolerant \\
\hline Cajanus cajan cv. IAPAR 43 & 111 & 25 & tolerant \\
\hline Lablab purpureus cv. Rongai & 189 & 37 & highly tolerant \\
\hline Vigna unguiculata & 192 & 38 & highly tolerant \\
\hline Mucuna aterrima & 229 & 44 & highly tolerant \\
\hline Mucuna deeringiana & 262 & 49 & highly tolerant \\
\hline Mucuna nivea & 334 & 59 & highly tolerant \\
\hline
\end{tabular}

The differential tolerance to $\mathrm{Al}$ by the species tested in this experiment could be related to Alexclusion mechanisms (Silva et al., 2000; Silva et al., 2002a) and/or symplast tolerance (Watanabe et al., 2001). The latter authors demonstrated in Melastoma malabathricum, a highly Al-tolerant and Al-accumulator, that oxalic acid was an important link agent to $\mathrm{Al}$ in the cell apoplast and symplast, allowing its accumulation, without serious damages in growth.

Exclusion mechanisms are based on the reduction of $\mathrm{Al}^{3+}$ activity in root tips, like the exudation of low molecular-weight organic compounds, which may form stable complexes with $\mathrm{Al}$, reducing its toxicity to roots, such as citrate (Miyasaka, et al., 1991), malate (Delhaize et al., 1993), polipetides (Basu et al., 1994) and flavonoids (Kidd et al., 2001), given that more than one type of organic acid may be released by Al-stressed roots (Larsen et al., 1998; Ma et al., 2000). There are strong evidences that Al-stimulation of organic acid excretion may be highly specific for $\mathrm{Al}$, and not other ions, by anionic channel in plasma membrane (Piñeros and Kochian, 2001). Other 
possible mechanism of $\mathrm{Al}^{3+}$ activity reduction could be the $\mathrm{H}^{+}$influx to the inside of cell, reducing the $\mathrm{Al}^{3+}$ solubility by higher $\mathrm{pH}$. Degenhardt et al. (1998) presented the first evidence of an Al-tolerance mechanism based on $\mathrm{pH}$ increase in rizosphere of an Arabidopsis thaliana mutant, tolerant to $\mathrm{Al}$ toxicity. On the other hand, Braccini et al. (2000a) demonstrated that rizosphere $\mathrm{pH}$-changes of coffee plants were not related to higher capacity of this specie to tolerate excess $\mathrm{Al}$ in soil.

Since the mechanisms to Al toxicity so far have elucidated excluded organic compounds in rizosphere, one may consider that the cultivation of plant materials in the same nutrient solution, as in the present experiment, may influence the plant reaction to $\mathrm{Al}$ toxicity. Nevertheless, several experiments for genotype selection to $\mathrm{Al}$ tolerance in the same nutrient solution have been successfully conducted (Furlani et al., 2000; Giaveno et al., 2001). Galvez and Clark (1991) demonstrated that two sorghum genotypes maintained their relative differences to Al toxicity tolerance independently if they were grown separately or in the same nutrient solution. A plausible explanation for this would be that the rizosphere chemistry changes might not influence on bulk solution chemistry. Whether rizospherechemistry changes by organic compounds or $\mathrm{pH}$ increase promoted by the plants tested in this work, is a strategy of differential tolerance to $\mathrm{Al}$ toxicity, remains a matter to be elucidated in further studies.

In acid soils, limestone application may reduce $\mathrm{Al}$ activity in solution, and it is a common practice in Brazil. Al-tolerant plants, in general, do not respond significantly to limestone addition in acid soils. Ernani et al. (2001) demonstrated that $C$. juncea was the tropical specie that most responded to limestone application in two acid soils (Latosol and Cambisol, Brazilian soil taxonomy) of Santa Catarina state, Brazil. These authors also documented that liming did not alter dry matter production in $M$. deeringiana and $M$. nivea in Latosol and $C$. ensiformis, $M$. aterrima and $C$. spectabilis in the Cambisol. Moreover, Hairiah and Van Noordwijk (1986), cited by Hairiah et al. (1990) verified that Mucuna pruriens var. utilis did not respond to $1 \mathrm{t} / \mathrm{ha}$ of limestone added to an acid soil of Nigeria. These results may be confronted to $\mathrm{Al}$ reaction of the plant materials tested in the present experiment (see Table 1).
The center of origin of the species tested may have a relation to Al reaction. Calegari (1995) reported that the species herein tested were originated from regions where the soils were predominately acid (von Uexküll and Mutert, 1995), mainly in South America, India and Africa. This could explain, in part, why the leguminous plants tested presented a predominant tolerant reaction to $\mathrm{Al}$, showing the capacity of these plants to overcome selection pressure by excess $\mathrm{Al}$ in soil. The fact that some plant materials were considered sensitive to $\mathrm{Al}$, could be due to the presence of neutral to alkaline soils in some sites of the tropics, where possibly these species could have been originated or domesticated (Kerridge, 1978).

Al tolerance is undoubtedly an ecological and agronomical advantage to plants and crops. Besides the $\mathrm{Al}$ tolerance observed in the leguminous plants tested in the present experiment, some studies indicated the possibility and necessity of breeding programs of leguminous cover crops considering its performance in acid soils, with high $\mathrm{Al}$ and low $\mathrm{P}$ contents, in order to explore the genetic variability existent in each specie (Mugwira and Haque, 1993). Research for plants considering this aspect would be useful for low-input agricultural productions and recovery of degraded soils and therefore minimize the impacts in environment.

The present work presented first comparison of $\mathrm{Al}$ tolerance in tropical leguminous plants used as cover crops in Brazil. It was possible to demonstrate that nutrient solution is still a practical and efficient tool for plant selection considering nutritional stresses.

\section{CONCLUSIONS}

1. Al concentration of $111 \mu \mathrm{mol} / \mathrm{L}$ in nutrient solution (or $23.8 \mu \mathrm{mol} / \mathrm{L}$ of $\mathrm{Al}$ activity) was the best to discriminate the plant materials tested;

2. Root elongation, rather than shoot and root dry matter, was the best parameter to compare $\mathrm{Al}$ tolerance among the leguminous plants;

3. Five leguminous cover crops were considered highly tolerant, four were tolerant, six were moderately tolerant and three were sensitive to Al toxicity. 


\section{RESUMO}

Leguminosas herbáceas são plantas de cobertura utilizadas como adubo verde que também atuam na recuperação de solos agrícolas. Devido aos benefícios econômicos e ambientais da adubação verde, tem aumentado consideravelmente a adoção desta técnica no Brasil. Entretanto, não há informações sobre estas espécies quanto à toxicidade de alumínio ( $\mathrm{Al})$. O presente estudo teve como objetivo avaliar 17 espécies de leguminosas quanto a tolerância ao alumínio. Também foram incluídas nos testes, três cultivares de soja e duas de milho. Houve uma grande diferença entre as espécies testadas, possibilitando de acordo com a metodologia empregada, a seguinte classificação: muito tolerantes (Mucuna nivea, $M$. deeringiana, $M$. aterrima Vigna unguiculata cv. BR 17 e Lablab purpureus cv. Rongai); tolerante (Cajanus cajan cv. IAPAR 43, Canavalia brasiliensis, Calopogonium mucunoides, Cajanus cajan cv. Fava larga, e Crotalaria paulina); moderadamente tolerante (Crotalaria ochroleuca, Canavalia ensiformis, Crotalaria spectabilis, e C. mucronata); sensível (Neonotonia wightii, Crotalaria breviflora e $C$. juncea cv.IAC-KR1). As três cultivares de soja foram classificadas em moderadamente tolerante (Biloxi) e tolerantes (IAC 13 e IAC 9).

\section{REFERENCES}

Alcântara, F. A.; Furtini Neto, A. E.; Paula, M. B.; Mesquita, H. A. and Muniz, J. A. (2000), Adubação verde na recuperação da fertilidade de um latossolo vermelho-escuro degradado. Pesq. Agrop. Bras., 35, 277-288.

Amabile, R. F.; Carvalho, A. M.; Duarte, J. B. and Fancelli, A.L. (1996), Efeito de épocas de semeadura na fisiologia e produção de fitomassa de leguminosas nos cerrados da região do Mato Grosso de Goiás. Sci. Agric., 53, 296-303.

Amado, T. J. C.; Mielniczuk, J.; Fernandes, S. B. V and Bayer, C. (1999), Culturas de cobertura, acúmulo de nitrogênio total no solo e produtividade de milho. Rev. Bras. Ciênc. Solo, 23, 679-686.

Archambault, D. J.; Zhang, G. and Taylor, G., (1997), Spatial variation in the kinetics of aluminium (Al) uptake in roots of wheat (Triticum aestivum L.) exhibiting differential resistance to Al. Evidence for metabolism-dependent exclusion of Al. J. Plant Physiol., 151, 668-674.
Arf, O.; Silva, L. S.; Buzetti, S.; Alves, M. C.; Sá, M. E. de; Rodrigues, R. A. F. and Hernandez, F. B. T. (1999), Efeitos na cultura do trigo da rotação com milho e adubos verdes, na presença e na ausência de adubação nitrogenada. Bragantia, 58, 328-334.

Barcelos, M. F. P.; Tavares, D. Q.; Miranda, M. A. C. and Germer, S. P. M. (1999), Aspectos químicos e bioquímicos de leguminosas enlatadas em diferentes estádios de maturação. Ciênc. Tecnol. Aliment.,19, 59-72.

Basu, U.; Basu, A. and Taylor, G. J. (1994), Differential exudation of polypeptides by roots of aluminumresistant and aluminum-sensitive cultivars of Triticum aestivum L. in response to aluminum stress. Plant Physiol., 106, 151-158.

Bernal, J. H. and Clark, R. B. (1998), Growth traits among sorghum genotypes in response to aluminum. J. Plant. Nutr., 21, 297-305.

Blancaflor, E. B.; Jones, D. L. and Gilroy, S. (1998), Alterations in the cytoskeleton accompany aluminum-induced growth inhibition and morphological changes in primary roots of Maite. Plant Physiol., 118, 159-172.

Braccini, M. C. L.; Martinez, H. E. P.; Braccini, A. L. and Mendonça, S. M. (2000a), Avaliação do pH da rizosfera de genótipos de café em resposta à toxidez de Al no solo. Bragantia, 59, 83-88.

Braccini, M. C. L.; Martinez, H. E. P.; Silva, E. A. M.; Braccini, A. L. and Scapim, C. A. (2000), Crescimento da planta e coloração das raízes com hematoxilina como critérios de avaliação de genótipos de café quanto a tolerância a toxidez de alumínio. Rev. Bras. Ciênc. Solo, 24, 59-68.

Calegari, A. (1995), Leguminosas para adubação verde de verão no Paraná. Londrina : IAPAR. 188 pp. (Circular; 80).

Debarba, L. and Amado, T. J. C. (1997), Desenvolvimento de sistemas de produção de milho no sul do Brasil com características de sustentabilidade. Rev. Bras. Ciênc. Solo, 21, 473-480.

Degenhardt, J.; Larsen, P. B.; Howell, S. H. and Kochian, L. V. (1998), Aluminum resistance in the Arabidopsis mutant alr-104 is caused by an aluminum-induced increase in rizosphere $\mathrm{pH}$. Plant Physiol., 117, 19-27.

Delhaize, E.; Ryan, P. R. and Randall, P. J. (1993), Aluminum tolerance in wheat (Triticum aestivum L.). II. Aluminum-stimulated excretion of malic acid from root apices. Plant Physiol., 103, 695-702.

Ernani, P. R.; Bayer, C. and Fontoura, S. M. V. (2001), Influência da calagem no rendimento de matéria seca de plantas de cobertura e adubação verde, em casa de vegetação. Rev. Bras. Ciênc. Solo, 25, 897-904.

Favero, C.; Jucksch, I.; Alvarenga, R. C.and Costa, L. M. (2001), Modificações na população de plantas espontâneas na presença de adubos verdes. Pesq. Agrop. Bras., 36, 1355-1362. 
Furlani, P. R.; Duarte, A. P. and Paterniani, M. E. A. G. Z. (2000), Tolerância ao alumínio em cultivares de milho. In: Duarte, A. P. and Paterniani, M. E. A. G. Z. (Eds.). Fatores bióticos e abióticos em cultivares de milho e estratificação ambiental: Avaliação IAC/CATI/Empresas - 1999/2000. Campinas : Instituto Agronômico. pp. 19-29. (Boletim Científico; 5).

Galvez, L. and Clark, R. B. (1991), Nitrate and ammonium uptake and solution $\mathrm{pH}$ changes for $\mathrm{Al}-$ tolerant and Al-sensitive sorghum (Sorghum bicolor) genotypes grown with and without aluminium. Plant Soil, 134, 179-188.

Giaveno, G. D.; Miranda Filho, J. B.and Furlani, P. R. (2001), Inheritance of aluminum tolerance in maize (Zea mays L.). J. Genet. Breed., 55, 51-56.

Hairiah, K.; Stulen, I. and Kuiper, P. J. C. (1990), Aluminium tolerance of the velvet beans Mucuna pruriens var. utilis and M. deeringiana. I. Effects of aluminium on growth and mineral composition. In: van Beusichem, M. L. (Ed.). Plant Nutrition Physiology and Applications. Dordrecht : Kluwer Academic Publishers. pp. 365-374.

Horst, W. J.; Schmohl, N.; Kollmeier, M.; Baluska, F. and Sivaguru, M. (1999), Does aluminium affect root growth of maize through interaction with the cell wall - plasma membrane - cytoskeleton continuum. Plant Soil, 215, 163-174.

Karlen, D. L.; Varvel, G. E.; Bullock, D. G. and Cruse, R. M. (1994), Crop rotations for the 21st century. Adv. Agron., 53, 1-45.

Kerridge, P. C. (1978), Fertilization of acid tropical soils in relation to pasture legumes In: Andrew, C. S. and Kamprath, E. J. (Eds.). Mineral nutrition of legumes in tropical and subtropical soils. Melbourne : Commonwealth Scientific and Industrial Research Organization. pp. 395-415.

Kidd, P. S.; Llugany, M.; Poschenrieder, C.; Gunsé, B. and Barceló, J. (2001), The role of root exudates in aluminium resistance and silicon-induced amelioration of aluminium toxicity in three varieties of maize (Zea mays L.). J. Exp. Bot., 52, 1339-1352.

Kollmeier, M.; Felle, H. H. and Horst, W. J. (2000), Genotypical differences in aluminum resistance of maize are expressed in the distal part of the transition zone. Is reduced basipetal auxin flow involved in inhibition of root elongation by aluminum? Plant Physiol., 122, 954-956.

Larsen, P. B.; Degenhardt, J.; Tai, C. Y.; Stenzler, L. M.; Howell, S. H. and Kochian, L. V. (1998), Aluminumresistant Arabidopsis mutants that exibit altered patterns of aluminum accumulation and organic acid release from roots. Plant Physiol., 117, 9-18.

Ma, J. F.; Yamamoto, R.; Nevins, D. J.; Matsumoto, H. and Brown, P. H. (1999), Al binding in the epidermis cell wall inhibits cell elongation of okra hypocotyl. Plant Cell Physiol., 40, 549-556.
Ma, J. F.; Taketa, S.; Yang, Z. M. (2000), Aluminum tolerance genes on the short arm of chromosome 3R are linked to organic acid release in triticale. Plant Physiol., 122, 687-694.

Mascarenhas, H. A. A.; Camargo, C. E.O. and Falivene, S. M. P. (1984), Efeito do alumínio sobre o crescimento de raízes, peso seco da parte aérea e raízes de diferentes cultivares de soja. Bragantia, 43, 191-200.

Meda, A. R.; Cassiolato, M. E.; Pavan, M. A. and Miyazawa, M. (2001), Alleviating soil acidity through plant organic compounds. Braz. Arch. Biol. Technol., 44, 185-189.

Minocha, R.; Minocha, S. C.; Long, S. L. and Shortle, W. C. (1992), Effects of aluminum on DNA synthesis, cellular polyamines, polyamine biosynthetic enzymes and inorganic ions in cell suspension cultures of a woody plant, Catharanthus roseus. Plant Physiol., 85, 417-424.

Miyasaka, S. C.; Buta, J. G.; Howell, R. K. and Foy, C. D. (1991), Mechanisms of aluminum tolerance in snapbeans - root exudation of citric acid. Plant Physiol., 96, 737-743.

Mugwira, L. M. and Haque, I. (1993), Screening forage and browse legumes germplasm to nutrient stresses: II. Tolerance of Lablab purpureus L. to acidity and low phosphorus in two acid soils. J. Plant Nutr., 16, 37-50.

Nascimento, P. C. and Lombardi Neto, F. (1999), Razão de perdas de solo sob cultivo de três leguminosas. Rev. Bras. Ciênc. Solo, 23, 121-125.]

Noble, A. D.; Fey, M. V. and Sumner, M. E. (1988), Calcium-aluminum balance and the growth of soybean roots in nutrient solutions. Soil Sci. Am. J., 52, 1651-1656.

Nordstrom, D. K. and May, H. M. (1989), Aqueous equilibrium data for mononuclear aluminum species. In: Sposito, G. (Ed.). The environmental chemistry of aluminum. Boca Raton : CRC Press. pp. 29-53.

Oliveira, T. K.; Carvalho, G. J. and Moraes, R. N. S. (2002), Plantas de cobertura e seus efeitos sobre o feijoeiro em plantio direto. Pesq. Agrop. Bras., 37, 1079-1087.

Olmos, J. and Camargo, M. N. (1976), Ocorrência de alumínio tóxico nos solos do Brasil, sua caracterização e distribuição. Ci. Cult., 28, 171-180.

Parker, D. R.; Zelazny, L. W. and Kinraide, T. B. (1987), Improvements to the program GEOCHEM. Soil Sci. Soc. Am. J., 51, 488-491.

Pavan, M. A. and Bingham, F. T. (1982), Toxidez de alumínio em cafeeiros cultivados em solução nutritiva. Pesq. Agropec. Bras., 17, 1293-1302.

Perin, A.; Guerra, J. G. M.; Teixeira, M. G.; Pereira, M. G. and Fontana, A. (2002), Efeito da cobertura viva com leguminosas herbáceas perenes na agregação de um argissolo. Rev. Bras. Ciênc. Solo, 26, 713-720. 
Piñeros, M. A. and Kochian, L. V. (2001), A patchclamp study on the physiology of aluminum toxicity and aluminum tolerance in maize. Identification and characterization of $\mathrm{Al}^{3+}$ - induced anion channels. Plant Physiol., 125, 292-305.

Severino, F. J and Christoffoleti, P. J. (2001), Banco de sementes de plantas daninhas em solo cultivado com adubos verdes. Bragantia, 60, 201-204.

Silva, D. M. and Sodek, L. (1997), Effect of aluminum on soybean nodulation and nodule activity in a vertical split-root system. J. Plant Nutr., 20, 963-974.

Silva, I. R.; Smyth, J. T.; Moxley, D. F.; Carter, T. E.; Allen, N. S. and Rufty, T. W. (2000), Aluminum accumulation at nuclei of cells in the root tip. Fluorescence detection using lumogallion and confocal laser scanning microscopy. Plant Physiol., 123, 543-552.

Silva, I. R.; Smyth, T. J.; Barros, N. F. and Novais, R. F., (2002a), Physiological aspects of aluminum toxicity and tolerance in plants. In: Alvarez, V. H.; Schaefer, C. E. G. R.; Barros, N. F.; Mello, J. W. V. and Costa, L. M. (Eds.). Tópicos em ciência do solo. Viçosa : Sociedade Brasileira de Ciência do solo. v. 2. pp. 277-335.

Silva, J. A. A.; Vitti, G. C.; Stuchi, E. S. and Sempionato, O. R. (2002b), Reciclagem e incorporação de nutrientes ao solo pelo cultivo intercalar de adubos verdes em pomar de laranjeira'pêra'. Rev. Bras. Frut., 24, 225-230.

Systat (2002), Disp. in: http://www.systat.com/ products/tablecurve2d. Accessed in: dec. 2002.

Spagnollo, E.; Bayer, C.; Wildner, L. P.; Ernani, P. R.; Albuquerque, J. A. and Proença, M. M. (2002), Leguminosas estivais intercalares como fonte de nitrogênio para o milho no sul do Brasil. Rev. Bras. Ciênc. Solo, 26, 417-423.
Testa, V. M.; Teixeira, L. A. J.and Mielniczuk, J. (1992), Características químicas de um podzólico vermelho-escuro afetadas por sistemas de culturas. Rev. Bras. Ciênc. Solo, 16, 107-114.

von Uexküll, H. R. and Mutert, E. (1995), Global extent, development and economic impact of acid soils. Plant Soil, 171, 1-15.

Watanabe, T.; Osaki, M. and Tadano, T. (2001), Al uptake kinetics in roots of Melastoma malabathricum L. - an Al accumulator plant. Plant Soil, 231, 283-291.

Wutke, E. B.; Fancelli, A. L.; Pereira, J. C. V. N. A. and Ambrosano, G. M. B. (1998), Rendimento do feijoeiro irrigado em rotação com culturas graníferas e adubos verdes. Bragantia, 57, 325-338.

Zonta, E. P.; Machado, A. A. and Silveira Júnior, P. (1987), Sistema de análise estatística para microcomputadores: manual de utilização. Pelotas. $145 \mathrm{pp}$.
Received: September 18, 2003; Revised: May 25, 2004; Accepted: November 30, 2004. 